\title{
Prototype of Rainfall Intensity Measurement Using CCD TSL1401CL Linear Sensor Array
}

\author{
Sixtinah Deswilan ${ }^{1}$, Aldo Novaznursyah Costrada ${ }^{1}$, Harmadi Harmadi ${ }^{1}$ \\ ${ }^{1}$ Department of Physics, Faculty of Mathematics and Natural Sciences, Universitas Andalas, Padang, Indonesia
}

Article Info

\section{Article History:}

Received: October 10, 2020

Revised: November 12, 2020

Accepted: February 04, 2021

\section{Keywords:}

beam expander

raindrops

rainfall measurement

linear sensor array

Corresponding Author:

Harmadi Harmadi

E-mail: harmadi@ sci.unand.ac.id

\begin{abstract}
A prototype measurement of rainfall intensity was developed using a CCD TSL1401CL linear sensor array. The prototype consists of a He-Ne laser that functions as a light source, which later is focused by the beam expander and conditioned by a convex lens. Each pixel will receive the same voltage depending on the light intensity so that it produces a decimal value of ADC. This ADC decimal value determines rainfall intensity based on the diameter and velocity of the raindrops. The diameter variations used ranges from $1 \mathrm{~mm}$ to $10 \mathrm{~mm}$, while for variations in the height of rainfall are $50 \mathrm{~cm}, 100 \mathrm{~cm}$, and $150 \mathrm{~cm}$. The test results proved that the greater the decimal value of the ADC is, the smaller the diameter of the raindrops detected will be, and vice versa. The values of the diameter and velocity of were used to obtain the value of rainfall intensity. The percentage value of error measuring rainfall intensity is $3.11 \%$ when compared to the rain gauge module is still considered rather accurate. However, direct testing is still needed when rain falls with various types and intensities.
\end{abstract}

Copyright $\odot 2021$ Author(s)

\section{INTRODUCTION}

Rain is part of the hydrological cycle and is strongly influenced by climate. Rain is a hydrometeor that falls in the form of water particles with a diameter of $0.5 \mathrm{~mm}$ or more (Maulidani, 2015). Rain reaching the ground surface can be measured by measuring the rainwater's height based on the volume of rainwater per unit area. The results of these measurements are called rainfall (Perdana et al., 2015), while the amount of rainfall in a unit of time is called the rainfall intensity. Rainfall intensity can be observed through raindrops with several parameters such as diameter, velocity, amount, and shape of raindrops (Kolte and Ghonge, 2016).

The diameter of the raindrops can be measured using several methods such as the staining method (the measurement of the stain on the dyed absorbent paper (Abudi et al., 2012)), the flour pellet method (the measurement of raindrops that get into the finely filtered flour and produced a dough pellet) (Junior et al., 2011), and modern methods (techniques for measuring raindrops automatically) (Sadeghi, 2013). The staining method and flour pelleting are based on observation; therefore, the data recording was performed manually, while in the modern method, the rainfall measurements are performed automatically. The modern methods utilize modern equipment such as electromechanical sensors (Abdullatif et al., 2012), electrostatic sensors (Muliantara et al., 2015), and optical detectors (Havizzullah et al., 2019; Awaluddin et al., 2019; Satriadi et al., 2020).

Several companies have developed modern equipment for rainfall measurement. These tools become references in determining the parameters of raindrops. Liu et al. (2013) had tested on tipping bucket rain gauge (TBRG), weighing rain gauge (WRG), optical rain gauge (ORG), present weather 
detector (PWD), Jos-Waldvogel detector (JWD), and 2-D video distrometer (2DVD). The test results proved that there were differences in the number of raindrops recorded by each instrument. The error percentage obtained ranged from $0 \%$ to $27 \%$. The optical instrumentation tools were more accurate in detecting raindrops when there was light rain with a small diameter $(D<0,3 \mathrm{~mm})$. The study also proved that the greater the event's diameter and time, the greater the rainfall intensity detected by the tool. Petru and Kalibova (2018) conducted a study using Thies Laser Precipitation Monitor (disdrometer) to measure the diameter, intensity, and kinetic energy of raindrops. The test results proved that the smaller the diameter is, the smaller is the raindrop's kinetic energy. However, the value of the rainfall intensity produced was greater as the frequency of occurrence increases. Later, Martinez et al., (2018) conducted an experiment testing raindrops by combining two types of optical disdrometers with two units of thies clima LPM and two units of OTT parsivel ${ }^{2}$. The tests were carried out by operating the four disdrometers simultaneously for two years. The test results proved that thies clima LPM detected more number and diameter variation of grain than OTT parsivel ${ }^{2}$. The resulting data causes differences in the value of rainfall intensity detected by the two devices.

Measurement of raindrops using tools designed by the companies mentioned earlier has several limitations, such as the relatively high price. In addition, not all devices can directly measure the diameter, velocity, and number of raindrops. Therefore, it is necessary to develop tools that yield various parameters of raindrops.

The tools for measuring raindrops have been developed using optical detectors (Havizzullah et al., 2019; Awaluddin et al., 2019; Satriadi et al., 2020). An optical detector can measure the raindrops based on imaging and scattering techniques. Havizzullah et al., (2019) developed an imaging technique using the Laser Speckel Imaging method with a forward scattering approach. The measurements were made using water dropped from a container with various pore diameters at different heights. The measurement of raindrops detected was only one grain per trial. Thus this method cannot be applied directly to see the overall raindrop image. Furthermore, scattering techniques had been developed using photodiode arrays (PDAs) and nRF24L01+ transceivers (Awaluddin et al., 2019). The photodiode array produced the rain measurement point more than one, so the measurement system was more accurate. But in this research, the photodiode array circuit design was tested manually so that the output voltage when the laser hit the photodiode array before being dropped by the rainwater kept changing (not stable). In addition, the output voltage when the sensor hits the rainwater produced less data, and there was no image of raindrops that occur. The scattering technique was also applied by using a Spectro pluviometer in determining the diameter and velocity of raindrops (Satriadi et al., 2020). This Spectro pluviometer was equipped with an infrared sensor as a wave transmitter and a photodiode as a wave receiver. The test proved that the greater the output voltage produced, the smaller the sensor's diameter will be. However, this condition is in reverse proportion to the greater velocity of raindrops. The research still has shortcomings as the tests were only up to $5 \mathrm{~mm}$ in diameter, and there were no parameters of the terminal velocity of the raindrops. Therefore, the tools used to measure the diameter and velocity of raindrops with various variations were expected to be developed to determine the rainfall intensity.

Based on the limitations of the research result tested by several previous kinds of research, the development for tools to measure rainfall intensity using a CCD TSL1401CL linear sensor array was carried out. The measurement system for rainfall intensity utilized a CCD TSL1401CL sensor consist of a He-Ne laser, beam expander, convex lens, and CCD TSL1401CL sensor. This method has advantages in detecting raindrop parameters, such as the diameter, voltage value, velocity of rainfall, and rainfall intensity, in order to conduct an overall monitor of rainfall.

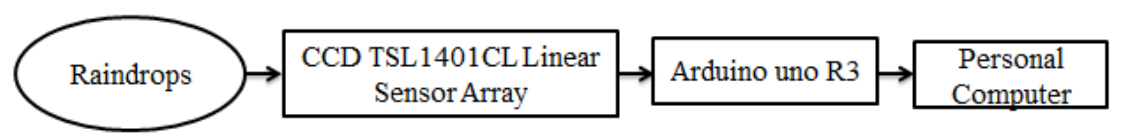

Figure 1 The hardware design of a water droplet detection system used CCD TSL1401CL 


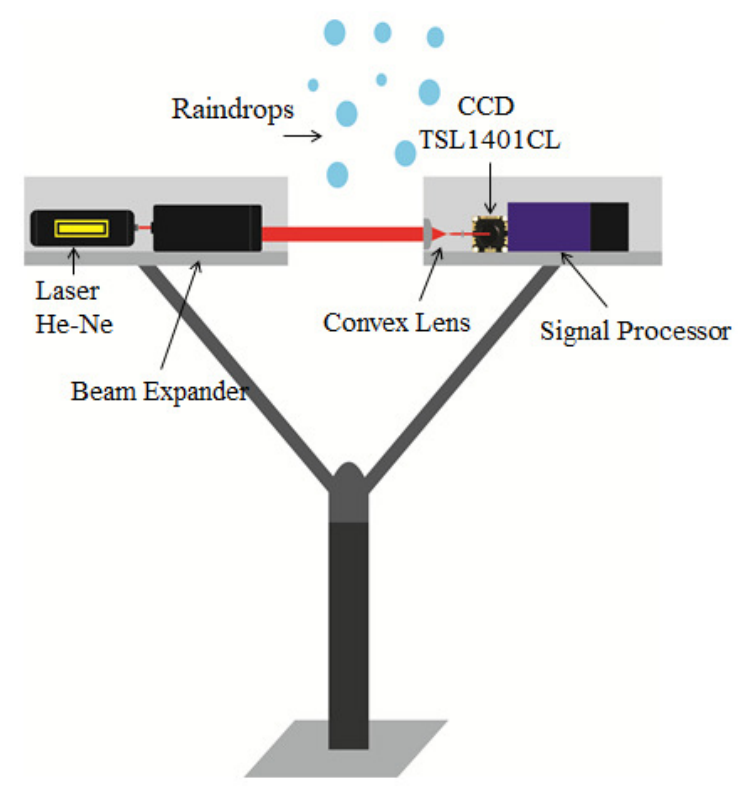

Figure 2 Scheme of diameter detector and the velocity of the raindrops

\section{METHOD}

The design of prototype hardware to measure the rainfall intensity using a CCD TSL1401CL can be seen in Figure 1. The raindrops pass through the CCD TSL1401CL so that these water droplets become input data to produce the values of the diameter, voltage, velocity, terminal velocity, and rainfall intensity.

The rain detector design includes a He-Ne laser, beam expander, convex lens, CCD TSL1401CL circuit, and Arduino Uno. The He-Ne laser was used as the light source with a wavelength of $632.8 \mathrm{~nm}$. When the light was emitted, the light was focused by the beam expander and conditioned by a convex lens so that it goes to the sensor element. Each pixel will receive the same voltage depending on the intensity of the light. The amount of charge obtained at each pixel was directly proportional to the light intensity and integration time. The sensor will pass each pixel value to the analog output terminal $(\mathrm{AO})$ one at a time until all the pixels were released.

After designing the device, the He-Ne laser was tested with the CCD TSL1401CL. The testing process was carried out by positioning the CCD TSL1401CL to precisely receive the He-Ne laser running light. The values of the output voltage detected by the CCD TSL1401CL determine the sensor detects the light intensity. The scheme for detecting the diameter and the velocity of the raindrops showed in Figure 2.

The diameter of the raindrops can be determined manually by assuming that the raindrops are round-shaped. The velocity of raindrops can be determined by the equation of free-fall motion regardless of air resistance. The velocity of rainfall can be determined in Equation (1).

$$
v_{j}=\sqrt{2 g h}
$$

where $v_{j}$ is the velocity of falling raindrops $(\mathrm{m} / \mathrm{s})$ to $j, g$ is the acceleration of gravity $\left(\mathrm{m} / \mathrm{s}^{2}\right)$, and $h$ is the height of falling raindrops. By height means the height of falling artificial raindrops that were 50 $\mathrm{cm}, 100 \mathrm{~cm}$, and $150 \mathrm{~cm}$.

Data in the form of raindrops diameter from model results were obtained from the transfer function between the voltage value and the raindrops model. The terminal velocity of the raindrops was obtained from Equation (2).

$$
v_{D}=9.65-10.3 \boldsymbol{e}^{-0.6 D}
$$

where $v_{D}$ is the model terminal velocity $(\mathrm{m} / \mathrm{s})$, and $D$ is the diameter of the model raindrop $(\mathrm{mm})$. 


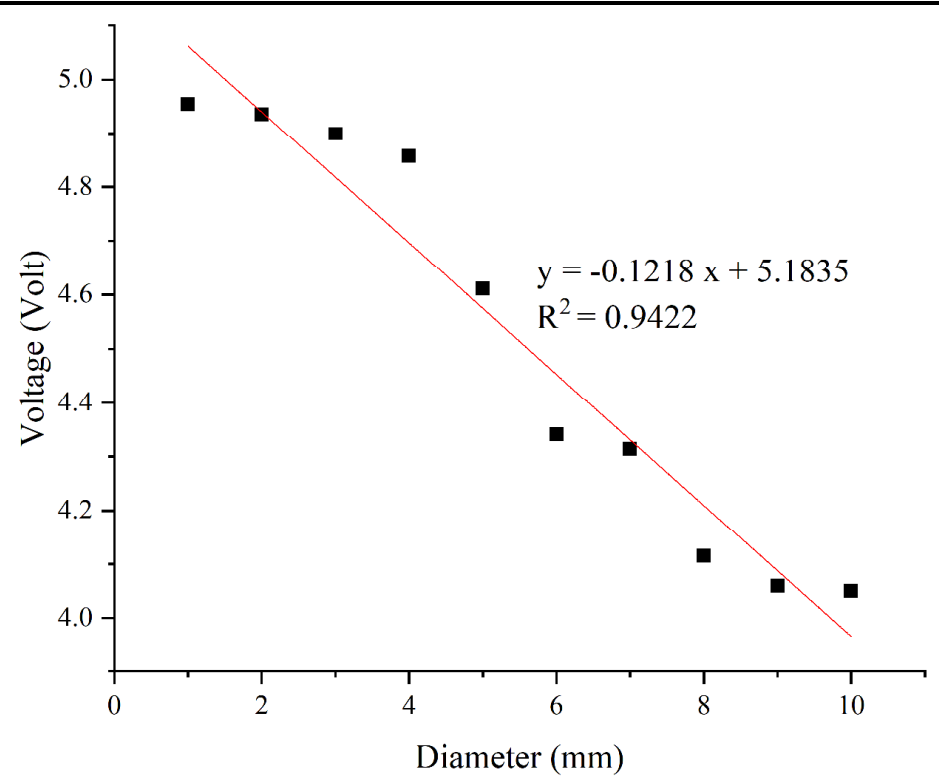

Figure 3 The graph of the relationship of the output voltage to the diameter of the raindrop model

The diameter of the raindrops from the model can determine the value of rainfall intensity. The rainfall intensity was calculated using the equation on the disdrometer (Parsivel). The size of the grains and the velocity of falling raindrops were grouped into 32 classes. Thus the total spectrum contained in the program was 1024 classes (32 x 32). DSD was calculated together with the rainfall intensity value using Equation (3), determined by the tool development company.

$$
R=\frac{2.1 \times 10^{-7}}{t} \cdot \sum_{i=1}^{n k l} \mathrm{Vn}_{i} \cdot D_{i}^{3}
$$

where $t$ is the observation time for one minute, $n$ is the number of grains in class $i$, and $D_{i}$ is the grain diameter in class $i$ (Marzuki et al., 2013)

The rainfall intensity value was analyzed to determine the accuracy level of the measurement system that has been conducted. The accuracy was the level of conformity or closeness measurement result to the actual value. The system's accuracy can be determined from the error percentage between the actual and the visible value (Equation 4).

$$
\varepsilon=\left|\frac{Y_{n}-X_{n}}{Y_{n}}\right| \times 100 \%
$$

where $\varepsilon$ indicates the error percentage value, $Y_{n}$ is the actual value on the comparator, and $X_{n}$ indicates the value that appeared on the measuring instrument.

\section{RESULTS AND DISCUSSION}

\subsection{The Testing of CCD TSL1401CL Linear Sensor Array with Raindrops Model}

Figure 3 shows the results of the CCD TSL1401CL test with the raindrops model. The diameters of the raindrops used range from $1 \mathrm{~mm}-10 \mathrm{~mm}$. This test was conducted to produce a relationship graph of the voltage value to the rain grain diameter model. The voltage value of the CCD TSL1401CL was inversely proportional to the raindrops' diameter, with the transfer function $y=-$ $0.1218 x+5.1835$. The variable $y$ was the physical quantity for the voltage value, while the variable $x$ was the quantity for the diameter. The transfer function states that every $1 \mathrm{~mm}$ change of diameter would affect the result in a change of the voltage value of $0.1218 \mathrm{~V}$. The value of $5.1835 \mathrm{~V}$ was the offset value which states that the initial voltage of the CCD TSL1401CL when the diameter was zero $5.1835 \mathrm{~V}$. Value of 0.9422 was the regression. Regression values closed to 1 proved that the measurement was close to the true value. 

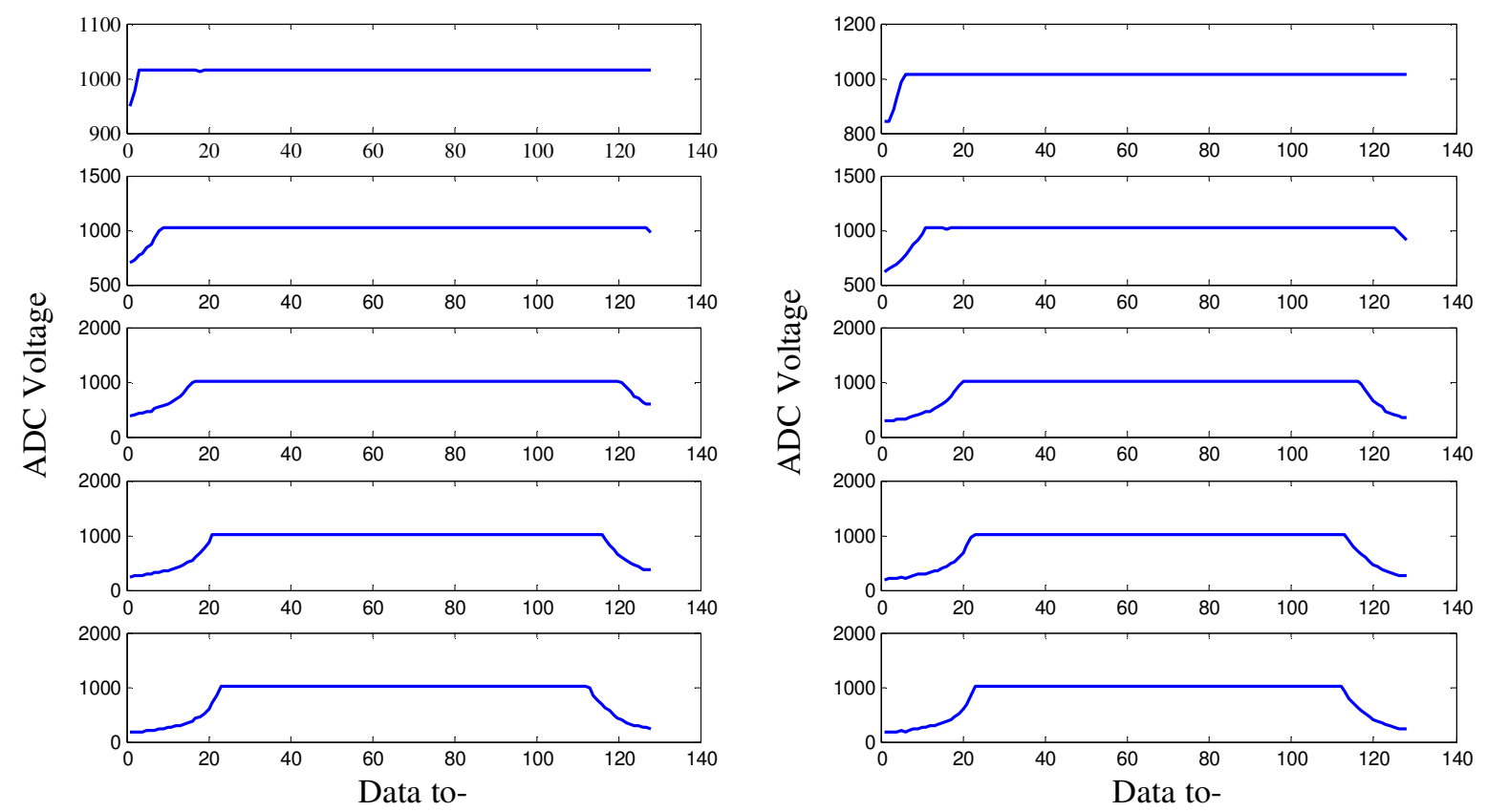

Figure 4 The graph model of raindrop diameter (a) $1 \mathrm{~mm}$ (b) $2 \mathrm{~mm}$ (c) $3 \mathrm{~mm}$ (d) $4 \mathrm{~mm}$ (e) $5 \mathrm{~mm}$ (f) $6 \mathrm{~mm}$ (g) 7 $\mathrm{mm}(\mathrm{h}) 8 \mathrm{~mm}(\mathrm{i}) 9 \mathrm{~mm}$ (j) $10 \mathrm{~mm}$

Figure 4 shows a graph of the raindrops model producing an output signal in an ADC decimal value. When the laser's light did not hit the raindrops as a barrier, it produced a bright phase with a value of above 1000. When passing through the barrier, there was a dark phase characterized by a downhill line. The phase change was due to a change in light intensity received by the CCD TSL1401CL sensor, resulting in analog voltage. The changed of ADC decimal value becomes a reference to determine the raindrop's diameter.

\subsection{Raindrop Velocity Testing}

Raindrops velocity testing was tested by observing the output voltage and diameter of the raindrops. The detected velocity values consist of fall velocity and terminal velocity of raindrops derived using Equation (1) and Equation (2) and given in Table 1.

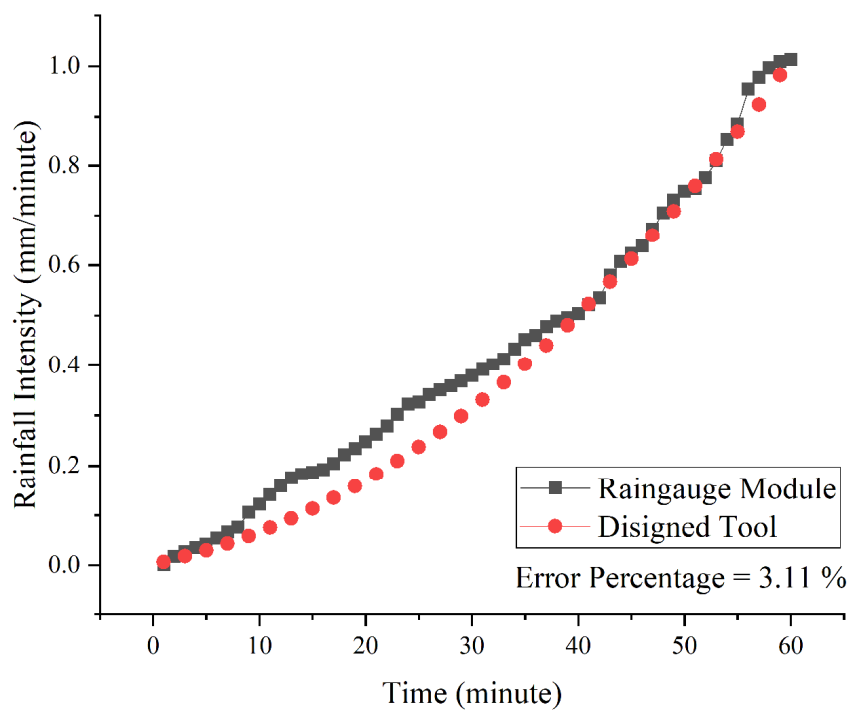

Figure 5 Testing of the designed rain detectors against rain gauge 
Deswilan et al.: Prototype of Rainfall Intensity Measurement Using CCD TSL1401CL Linear Array Sensor

\begin{tabular}{|c|c|c|c|c|c|c|c|}
\hline $\begin{array}{c}\text { Water } \\
\text { Drop } \\
\text { Height } \\
(\mathbf{m m})\end{array}$ & $\begin{array}{c}\text { Raindrops } \\
\text { Diameter } \\
\text { (mm) }\end{array}$ & $\begin{array}{l}\text { Time } \\
(\mathrm{ms})\end{array}$ & $\begin{array}{l}\text { Voltage } \\
\text { Output } \\
\text { (Volt) }\end{array}$ & $\begin{array}{c}\text { Decimal } \\
\text { ADC }\end{array}$ & $\begin{array}{l}\text { Diameter } \\
(\mathbf{m m})\end{array}$ & $\begin{array}{c}\text { Fall } \\
\text { Velocity } \\
(\mathbf{m m} / \mathbf{m s})\end{array}$ & $\begin{array}{l}\text { Terminal } \\
\text { Velocity } \\
(\mathrm{mm} / \mathrm{ms})\end{array}$ \\
\hline \multirow{10}{*}{500} & 1 & 844 & 4.979 & 1018.759 & 1.676 & 3.162 & 5.881 \\
\hline & 2 & 758 & 4.914 & 1005.361 & 2.213 & 3.162 & 6.920 \\
\hline & 3 & 602 & 4.674 & 956.325 & 4.182 & 3.162 & 8.812 \\
\hline & 4 & 594 & 4.494 & 919.553 & 5.658 & 3.162 & 9.304 \\
\hline & 5 & 469 & 4.059 & 830.400 & 9.237 & 3.162 & 9.610 \\
\hline & 6 & 430 & 3.584 & 733.273 & 13.135 & 3.162 & 9.646 \\
\hline & 7 & 406 & 3.331 & 681.596 & 15.210 & 3.162 & 9.649 \\
\hline & 8 & 352 & 2.563 & 524.444 & 21.518 & 3.162 & 9.650 \\
\hline & 9 & 289 & 1.985 & 406.189 & 26.265 & 3.162 & 9.650 \\
\hline & 10 & 156 & 1.222 & 250.000 & 32.535 & 3.162 & 9.650 \\
\hline \multirow{9}{*}{1000} & 1 & 1078 & 4.980 & 1018.993 & 1.666 & 4.472 & 5.860 \\
\hline & 2 & 945 & 4.916 & 1005.736 & 2.198 & 4.472 & 6.896 \\
\hline & 3 & 906 & 4.770 & 976.043 & 3.390 & 4.472 & 8.303 \\
\hline & 4 & 750 & 4.595 & 940.135 & 4.832 & 4.472 & 9.083 \\
\hline & 5 & 617 & 4.270 & 873.709 & 7.498 & 4.472 & 9.535 \\
\hline & 6 & 609 & 3.991 & 816.654 & 9.788 & 4.472 & 9.621 \\
\hline & 7 & 602 & 3.873 & 792.338 & 10.764 & 4.472 & 9.634 \\
\hline & 8 & 563 & 3.471 & 710.111 & 14.065 & 4.472 & 9.648 \\
\hline & 9 & 461 & 3.021 & 618.000 & 17.763 & 4.472 & 9.650 \\
\hline \multirow{11}{*}{1500} & 10 & 430 & 2.511 & 513.782 & 21.946 & 4.472 & 9.650 \\
\hline & 1 & 1336 & 4.981 & 1019.146 & 1.660 & 5.477 & 5.846 \\
\hline & 2 & 1188 & 4.918 & 1006.178 & 2.181 & 5.477 & 6.866 \\
\hline & 3 & 930 & 4.817 & 985.622 & 3.006 & 5.477 & 7.953 \\
\hline & 4 & 758 & 4.681 & 957.711 & 4.126 & 5.477 & 8.784 \\
\hline & 5 & 664 & 4.552 & 931.329 & 5.185 & 5.477 & 9.191 \\
\hline & 6 & 648 & 4.431 & 906.566 & 6.179 & 5.477 & 9.397 \\
\hline & 7 & 633 & 4.310 & 881.827 & 7.172 & 5.477 & 9.511 \\
\hline & 8 & 586 & 4.143 & 847.693 & 8.542 & 5.477 & 9.589 \\
\hline & 9 & 469 & 4.015 & 821.450 & 9.596 & 5.477 & 9.617 \\
\hline & 10 & 445 & 3.885 & 794.842 & 10.664 & 5.477 & 9.633 \\
\hline
\end{tabular}

When the raindrops' diameter was the same, and the height of falling raindrops was higher, then the time of raindrops and voltage were showed greater output. If the diameter was bigger and the height of raindrops was the same, then the time of raindrops and the output voltage will get smaller. Thus, the bigger the raindrops' diameter, the greater the velocity of the grain terminal will be. The data also proved that at the height of $150 \mathrm{~cm}$, the values of diameter, terminal velocity, and the fall velocity of raindrops were closer to the actual value compared to the height of $50 \mathrm{~cm}$ and $100 \mathrm{~cm}$.

The results of tests conducted according to the test graphs carried out by Satriadi et al., (2020) proved that there is a relationship between terminal velocity and raindrops diameter. The study's result suggested that the raindrops diameter of $0.5 \mathrm{~cm}$ showed $914 \mathrm{~cm} / \mathrm{s}$ terminal velocities, whereas the research that had been carried out produced a terminal velocity of $9.610 \mathrm{~mm} / \mathrm{ms}$ or $961 \mathrm{~cm} / \mathrm{s}$ with a diameter of $5 \mathrm{~mm}$. 
Based on the data obtained, obtained data, it can be concluded that the terminal velocity was directly proportional to the diameter of the raindrop. The terminal velocity influences the diameter of the raindrop. The greater the diameter is, the greater the terminal velocity will be.

\subsection{Test Results for Rain Detection Devices Designed against Rain gauge Module Comparators}

The tool test was examined by looking at the accuracy of the rain detector designed. The test was performed by comparing the measurement device designed with the rain gauge module. The raindrop model's diameters were the same in every condition, which was $3 \mathrm{~mm}$ and $4 \mathrm{~mm}$, and the data retrieval time was 1 minute.

Figure 5 shows the results of testing a rain detector that was designed against a rain gauge. The rainfall intensity in the tool designed was $0.982 \mathrm{~mm} /$ minute, while the intensity in the rain gauge was $1.012 \mathrm{~mm} /$ minute. The rainfall intensity that is greater than $1(R>1)$ signifies heavy rain. The error percentage between the designed rain detector and the rain gauge was $3.11 \%$. The tool system was designed using the optical principle while the rain gauge applies the magnet principle. However, the error percentage of $3.11 \%$ can be considered rather accurate because the research conducted by Liu et al. (2013) with some rain gauges had an error rate of $0 \%$ to $27 \%$. Thus, it can be concluded that the tool designed is considered successful in detecting raindrops.

\section{CONCLUSION}

This research had successfully developed a rainfall measuring instrument using a CCD TSL1401CL. It can be seen from the accuracy of the measurement for the diameter, fall velocity, and rainfall intensity. The greater the ADC's decimal value, the smaller the diameter of the raindrops detected will be. The value of the velocity of the raindrop obtained was close to the value obtained by Satriadi et al. (2020). The diameter values and the velocity of rainfall were used to acquire rainfall intensity values. The error percentage value of rainfall intensity was $3.11 \%$ when compared to the rain gauge module. However, direct testing is still required when rain falls with various types and intensities.

\section{ACKNOWLEDGEMENT}

This research supported by Directorate of Research and Public Service, Deputy of Affirmation Research and Development Sector, The Ministry of Research, Technology, and Higher Education /National Research and Innovation Agency (commission contract of public service program number No. T/36/UN.16.17/ PT.01.03/AMD/PT-Kebencanaan/2020). The author would like to thank the editorial team of the Jurnal Ilmu Fisika (JIF) and two anonymous reviewers.

\section{REFERENCE}

Abdullatif, F., Hartono, \& Uletika, N.S. (2015). Rancang Bangun Sitem Pemantau Curah Hujan Secara Real Time Menggunakan Sensor Kecepatan Aliran Fluida Degan Efek Hall. Proseding Seminar Nasional Pengembangan Sumber Daya Pedesaan dan Kearifan Lokal Berkelanjutan II, 1-6.

Abudi, I., Carmi, G., \& Barliner, P. (2012). Rainfall Simulator for Field Runoff Studies. J.Hydrol, 454, 76-81.

Awaluddin, Harmadi, \& Marzuki. (2019). Rancang Bangun Sistem Pengukuran Diameter Butiran Air Menggunakan Fotodioda Array dan Transceiver nRF24L01+. Jurnal Ilmu Fisika, 11, 88-94.

Havizzullah, Harmadi, \& Marzuki. (2019). Analisis Kecepatan Aliran Air Berbasis Metode Laser Speckle Imaging. Jurnal Fisika Unand, 8, 178-183.

Junior, S.S., \& Siqueira, G.Q. (2011). Development and Calibration of a Rainfall Simulator for Urban Hydrology Research. Proccedings of 12th International Conference on Urban Drainage, 226-231.

Kolte, G., \& Ghonge, P.A. (2016). An Image Processing Based Raindrop Parameter Estimation. International Journal Of Engineering trens and Technology (IJETT), 31,73-77.

Liu, X.C., Gao, T.C., \& Liu, L. (2013). A Comparison of Rainfall Measurement from Multiple Intruments. Atmospheric Measurement Techniques, 6, 1585-1595. 
Deswilan et al.: Prototype of Rainfall Intensity Measurement Using CCD TSL1401CL Linear Array Sensor

Martinez, M.A., Begueria, S., Latorre, B., \& Raga, M.F. (2018). Comparison of Precipitation Measurements by OTT Parsivel2 and Thies LPM Optical Disdrometers. Hydrology and Earth System Sciences, 22, 28112837.

Marzuki, M., Hashiguchi, H., Yamamoto, M. K., Mori, S., and Yamanaka, M. D. (2013) Regional variability of raindrop size distribution over Indonesia, Ann. Geophys., 31, 1941-1948, https://doi.org/10.5194/angeo31-1941-2013, 2013.

Maulidani, S.S., Ihsan, N., \& Sulistiawaty. (2015). Analisis Pola dan Intensitas Curah Hujan Berdasarkan Data Observasi dan Satelit Tropical Rainfall Measuring Mission (TRMM) 3B42 V7 di Makasar. Jurnal Sains dan Pendidikan Fisika (JSPF), 11, 98-103.

Muliantara, A., Senjaya, N.A., \& Widiarta, I.M. (2015). Perancangan Alat Ukur Ketinggian Curah Hujan Otomatis Berbasis Mikrokontroler. Jurnal Ilmiah Ilmu Komputer, 8, 31-37.

Perdana, D.A., Zakaria, A., \& Sumiharni. (2015). Studi Permodelan Curah Hujan Sintetik dari Beberapa Stasiun di Wilayah Pringsewu. JRSDD, 3, 45-56.

Petru, J., \& Kalibova, J. (2018). Measurement and Computation of Kinetic Energy of Simulted Rainfall in Comparison with Natural Rainfall. Soil\& Water Research, 13, 226-233.

Sadeghi, S.H., Abdollahi, Z., \& Darvishan, A.K. (2013). Experimental Comparison of Some Techniques for Estimating Natural Raindrop Size Distribution on the South Coast of the Caspian Sea. Hydrol. Sci. J, 58, 1374-1382.

Satriadi, Y., Sudiarta, I.W., \& Kurniawidi, D.W. (2020). Permodelan Pengukuran Diameter dan Kecepatan Jatuh Butiran Hujan Menggunakan Alat Spektro Pluviometer. Indonesia Physics Review, 3, 1-5. 